\title{
開拓使札幌本庁工業局の器械場について \\ A STUDY ON THE SAPPORO FACTORY OF INDUSTRIAL BUREAU OF THE KAITAKUSHI
}

\author{
吳 農*, 越野 武**, 角 幸博*** \\ Nong WU, Takeshi KOSHINO and Yukihiro KADO
}

\begin{abstract}
The Kaitakushi, or Colonization Commission (1869-1882) built many of the model factories since 1871 in order to exploit the natural resources in Hokkaido. The Sapporo Factory of Industrial Bureau was one of those important factories during that period, and included wood processing mills, smiths, iron manufacture shop. and casting shops etc. In this paper its planning of location, layout and relations between the buildings and the product system have been clarified.
\end{abstract}

Keyword: The Kaitakushi, Hokkaido, Sapporo, Industrial bureau, Meiji era 開拓使、北海道、札幌、工業局、明治期

\section{1 緒言}

開拓使（1869～82）官営工場こついては、開拓使事業報告』1，

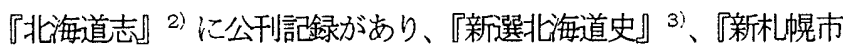
史』4) 等にも概要が記述されている。建築史の分野でも遠藤明久 『開拓使営絙事業の研究』 ${ }^{5}$ ほかて触れられているが、基本的には 上に記した公刊記録や地方史の記述を越えるものではなかった。こ れらの記述内容は日本に㧍沙る風技術導入期の産業施設としての 重要性から見下、物足りないと言わざるを得ない。本庁工業局管轄 以外のものを含めて、広く北海道各地に展開された開拓使の官営工 場施設全体について、精細な研究が必要であるが、本稿 ${ }^{(3)}$ はまず、 札幌本庁工業局の器械場（工作場、器找所、製作場などとも称され たが、以下器械場という）をとりあげ、生産施設としての立地計画、 施設配置及び主要な各工場建物こついて考察しようとするものであ る。

基本史料として、北海道立文書館所蔵簿書類の『明治十六年札幌 工業管理局引継書類』、明治十五年二月開拓使工業課事務受渡書 類』など、北海道大学附属図書館北方資料室所藏の図類、写真执よ びケプロン (Horace Capron) の日誌》などを用いる。

\section{2 開拓使の官営諸工場と器械場の概要}

周知のように、開拓使は明治政府の殖産興業政策に対応し、北海
道内自給体制の確立と輸出産業の創出を方針として 8 、明治 4 年 （1871）以降指尊的、模範的な各種官営工場を設立していた。開 拓使による諸工場の数は、統廃合したものを入れると 43 工場で、 その設置の状況を、年次別、本支宁管内別に示寸と表 1 のように なる。地域別には、札幌が主力であって、43 工場のうち、26が札 幌本庁管内に污か冰た。札幌本庁では、工業局管轄下に器械場構内 の蒸気木挽器械所 (蒸気器械所、蒸気機械所)、水車器械所 (水車 器械製造所)、木工所 (木工塗場)、鉒工所 (棟鉄所、第 1 棟鉄所)、 鉒冶場 (第 2 棟鉄所)、第 $1 、 2$ 鋳造所、製鉄器械所 ${ }^{9}$ (製鉄所) の 8 工場、さらに厚別水車器械所 ${ }^{10}$ 、室蘭港蒸気器械場を、その 他の農産物加工を主とする諸工場泩物産局の管轄におき、他支庁で はすべて民事課の下に所属させた。なお、開拓使の設置した諸工場 の他に、紋別（現伊達市）には内務省勧農局によって製糖所が設け られている。

器械場は「机幌本庁草創ノ際道路橋梁习建築シ庁舍家宅习造営ス ル八開拓使ノ最モ要務二属スル」以いら背景のもとに設置され、 開拓使が最も力を入れた本格的な総合工業施設である。明治 4 年に 開拓使次官黒田清隆 12 が蒸気円鋸機械、水車元車之付属機械をア メリカから購入した。翌 5 年 2 月開拓使は、器械方頭取ホルト (N・ $\mathrm{W} \cdot$ Holt） ${ }^{18)}$ と器械方補助サンドフォード・クラーク（S andford
$*$ 北海道大学大学院工学研究科 大学院生 - 修士 (工学)

** 北海道大学大学院工学研究科 教授・工博

*** 北海道大学大学院工学研究科 助教授・博士 (工学)
Graduate Student, Graduate School of Eng., Hokkaido Univ, M. Eng. Prof., Graduate School of Eng., Hokkaido Univ., Dr. Eng.

Assoc. Prof., Graduate School of Eng., Hokkaido Univ., Dr. Eng. 
【表 1】

\begin{tabular}{|c|c|c|c|c|}
\hline 設立年 & 札 㹸 & 本庁管轄 & 函館支庁管轄 & 根窒支庁管轄 \\
\hline (明治) & 工業局 & 物 産 局 & (民事局) & (民事局) \\
\hline 4 & & 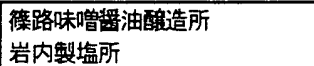 & & \\
\hline 5 & 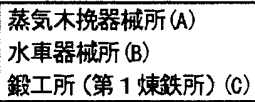 & & \begin{tabular}{|l|} 
棟化石及屋瓦製造所 \\
石灰製造所 \\
製革所
\end{tabular} & \\
\hline 6 & 第 1 錆造所 (D) & 製紙所 & 七重製紙所 & . \\
\hline 7 & 室蘭器湘所 & & & \\
\hline 8 & 木工所 (E) & $\begin{array}{l}\text { 製油所・馬具製造所・製革所 } \\
\text { 製網所 }(J) \cdot \text { 裂糸所 (紡織所) }(\mathbb{K})\end{array}$ & & \\
\hline 9 & 第 2棟叙所 & 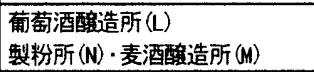 & & 酰熏繁所 \\
\hline 10 & & $\begin{array}{l}\text { 第 } 1 \text { 味増罾油製造所 (P) } \\
\text { 石狩罐詰製造所 }\end{array}$ & $\begin{array}{l}\text { 七重水車埸 } \\
\text { 䱋肝油製造所 }\end{array}$ & 昆布乾燥所 \\
\hline 11 & 第 2 鉡造所 (G) & $\begin{array}{l}\text { 札幌製物試験場 (0) } \\
\text { 美々罐詰製造所 }\end{array}$ & 馬具铁器製造所 & $\begin{array}{l}\text { 別海䧸詰製造所 } \\
\text { 魚粕製造所 }\end{array}$ \\
\hline 12 & 製鉄所 $(\mathrm{H})$ & 第 2 味増㯰油㱔造所 (R) & $\begin{array}{l}\text { 七重製棟所 } \\
\text { 檖木裂造所 }\end{array}$ & 紗那故詰声製造所 \\
\hline 13 & 厚別水車器械所 & & & $\begin{array}{l}\text { 厚岸罐詰製造所 } \\
\text { 製革所・木婏器械所 }\end{array}$ \\
\hline
\end{tabular}

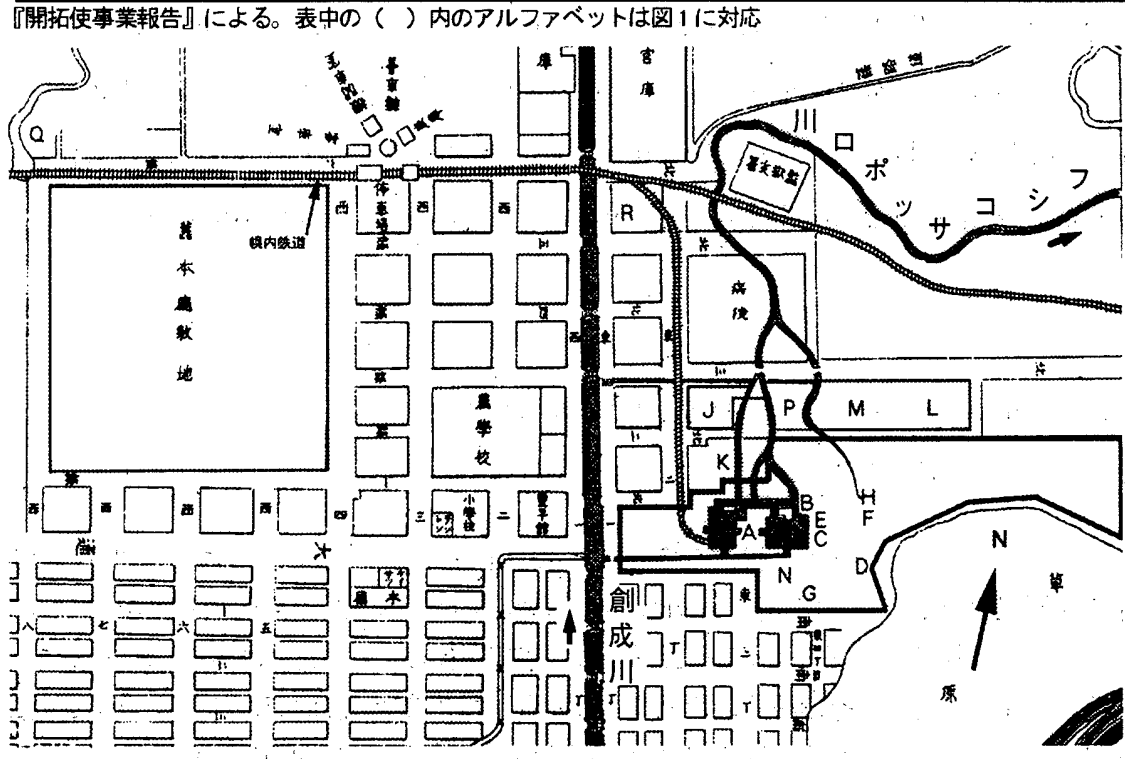

【図1】札幌市街内部分官営工場分布図

『北海道志』中の「札幌市街图」による。図中のアルファベットは表りに対応

Clark) ${ }^{14}$ を雇い５月から「札幌東創成通工業課構内」に蒸気木 挽器械所と水車器械所の建設に着手し、ほほ同時に鍛工. 12 人を東 京から招き鍛工所を建てた。蒸気器械所は同年 7 月に完成し、S · クラークが指導に当たり、洋式鋸を据え付け、職工 8 人に機械の 運車を伝習した。水車器械所は 5 年 6 月に一応出来上がったもの の、すべての完成には、8 年 3 月までほぼ 2 年半以上を要したので あった。この 2 器械所を中心として、そのほか 6 年 5 月に鋳造所、 8 年 6 月木工所、 9 年 11 月製粉器械所 (明治 10 年 12 月物産局治 所属)、12 年 7 月製鉄器械所が次々と設置された。

明治 12 年度から作業条例 ${ }^{15}$.により器械場は、蒸気木挽器械所、 水車器械所、木工所、棟鉄所、第 1 鋳造所、製鉄所、厚別水車器械 所の7部に区別された。しかし、帮際の作業にあたっては、例えば 農具の鉄工部分を作る場合、ます棟鉄所で鉄を鉎鍊して形をつくり、 これを製鉄所で金属加工機械を使って精製するというように，相互 に関連をもつていたのである。つまり器械場は，角材、屋根柾など の建設資材のほか、農具、船具などの諸道具器械、車 㮃、鰊釜 ${ }^{16)}$ 、 度量衡などの生産用具といた多品目の製造と修繥を゙行い、官需品の ほか壖品向けの製品も製造したのである。
同工場は、開拓使廃止後、その後継機関であ る北海道事業管理局により官業で継続操業した が、明治 17 年 (1884) 5 月には、水車器械所、 木工所、蒸気木挽器械所を合併して、「札幌木 工場」、また棟鉄所、鋳造所、製鉄器械所の鉄 工関係の製造所を合併して「札幌鉄工場」とし 事業を続けることとなった。北海道庁発足時の 明治 19 年ここれらの工場の事業は一旦停止さ れ、翌 20 年民間に払い下洴られた。

\section{3 器诚埸の位置}

周知のように開拓使により初期札幌の都市計 画では、大通を境に北側の官用地と南側の町屋 地が設定されたが、さらに、官用地のうち創成 川から東方の地区を官営工場用地と定め、主題 の工業局管轄の器械場 $(\mathrm{A} \sim \mathrm{H})$ と、紡織所 $(\mathrm{K})$ 、 製網所 $(\mathrm{J})$ 、麦酒酚造所 $(\mathrm{M})$ ）などの物産局 管轄の工場を、逐年、建設した (表 1 ，図 1)。

器械場の敷地は、現在の創成川の東側、大通 り公園の東突き当たり付近にある。創成川は慶 㐫 2 年 (1866)、大友亀太郎の開削になる大友 堀をその後明治 $2 \sim 7$ 年、開拓使が開削しなお し、さらに北 6 条以北も直通の運河としていた。 その目的開拓物資の輸送路とすることである が、ケプロンの日誌こ「1873 年7月 7 日 … すべて機械を動かす水は、町を通る運河（創成 川）で豊平川から引いて来る。水は、すべての 機械の動力になる上同時に、水路の役目をして、 上流近くて伐採する丸太を流して、大きな貯水 池へいれる。…（（）内は引用者の補足。以 下同）とあるように、器械場への原材料搬入と ともに、水動力をも提供した。すなわち、創成 川は、南 6 条東 1 丁目付近に豊平川加らの流 入口をもち、大通東 1 丁目の水路加器械場 の「木材囲堀」に分岐、この水力を利用して水車器械所の機械を動 かすと同時に、豊平川上流で伐採した原木はこの水系を使って運搬 したのである。

器械場の北側は「勧業製系所」(札幌紡織場)、札幌葡萄酒酸造所、 札幌麦酒酾造所の用地に隣接する。南側には町屋地が広がり、東南 の隅には「豊平川支流古川筋」がある。その敷地は、南北が約 1377 尺、 $(417.2 \mathrm{~m})$ 東西が約 4804 尺 $(1455.6 \mathrm{~m})$ であった。簿書 $(7764)$ 『明治十六年札幌工業管理局引継書類】中の配置図「北海道石狩国 札幌区工作場構内千式百分壱之図面（図 2）に、規模は 82,799 坪9合 (約 $\left.273,720 \mathrm{~m}^{2}\right)$ ）と記されている。構内の施設は、西半分 に集中しており、東半分は簿書 (2518) 『明治十一年 各局文移録 営䌒課』に

\section{「上局”勧業課}

工業局工作場水車器械場裏草芷ノ地御雇教師ボーマン氏並培盖係 ノ方一実地検查為致候處葡萄植付適応ノ地卜点候間別紙概図ノ場 所同局二テ即今着手スル用途無之候得共葡薙植付訌験場卜シテ引 渡候様御指揮相成度... 
【表 2】

器械場構内工業局所管建策一覧

\begin{tabular}{|c|c|c|c|c|}
\hline 番号 & 建物名 & 竣工年月 & 構造 & 坪数 \\
\hline 1 & |旧工業局（工業局） & 10.6 & 2 階 & 110.86 \\
\hline 2 & 巡查交番所 & & 平家 & 3.50 \\
\hline 3 & 門番所（門候所） & & 平家 & 8.50 \\
\hline 4 & 蒸気木挽器械所 & 5.7 & 平家 & 81.25 \\
\hline 5 & 水車器械所 & 8.6 & 2 階 & 125.19 \\
\hline 6 & 木工所 & 8.3 & 2階 & 132.00 \\
\hline 7 & 第 1 䗲鉄所（蝀铁所） & 6.1 & 平家 & 129.00 \\
\hline 8 & 第 2蝀铁所（鍛冶埸） & 7.1 & 平家 & 74.75 \\
\hline 9 & 製鉄器械所（製猞所） & 12.7 & 平家 & 108.50 \\
\hline 10 & 第 1 錆造所 & 8.2 & 平家 & 144.00 \\
\hline 11 & 第 2 鋳造所 & 11.1 & 平家 & 129.50 \\
\hline 12 & 石灰場並置所共（石灰置所と石灰釜附薪置所） & & 平家 & 40.83 \\
\hline 13 & 厩 & 8.11 & 平家 & 69.00 \\
\hline 14 & 吹拔細工小屋 & & 平家 & 75.00 \\
\hline 15 & 吹报細工小屋（元度量衡細工所） & & 平家 & 93.00 \\
\hline 16 & 諸品庫（一番二番板庫） & & 平家 & 49.00 \\
\hline 17 & 諸品庫（三番四番五番六番板庫） & & 平家 & 122.50 \\
\hline 18 & 諸品庫（諸品板庫） & & 平家 & 110.00 \\
\hline 19 & 製造品置所（制作物置所） & & 平家 & 93.00 \\
\hline 20 & 木枯温室（木枯小屋） & 13. & 2 階 & 40.00 \\
\hline 21 & 消防道具置所 & & 平家 & 24.75 \\
\hline 22 & 木枯小屋（木枯小屋） & & 平家 & 79.00 \\
\hline 23 & 木枯仮小屋 (木材小屋) & & 平家 & 48.00 \\
\hline 24 & 木枯小喔（木枯小屋） & & 平家 & 100.89 \\
\hline 25 & 木枯仮小尿（木材置所） & & 平家 & 95.00 \\
\hline 26 & 薪置仮小屋（薪置小屋） & & 平家 & 32.00 \\
\hline 27 & 仮建物置小屋（制作諸品両係用物置） & & 平家 & 195.00 \\
\hline 28 & 木枯小屋（木枯小痽木枯吹报小屋） & & 平家 & 90.00 \\
\hline 29 & 仮建土樋置所（蝀化置所） & & 平家 & 20.00 \\
\hline 30 & 物置所 (水車器械所所属物置) & & 平家 & 18.00 \\
\hline 31 & 木枯小尿（木工所所属木枯小屋） & & 平家 & 133.00 \\
\hline 32 & 木枯小屋（製作所属木枯小屋） & & 平家 & 50.00 \\
\hline 33 & 柾置小屋（製作柾置所） & & 平家 & 108.50 \\
\hline 34 & 吹拔細工小屋（木材小屋） & & 平家 & 100.00 \\
\hline 35 & 木枯小屋（木枯吹抜小屋） & & 平家 & 42.50 \\
\hline 36 & 物置仮小尿（物置所） & & 平家 & 10.00 \\
\hline 37 & 㳇物所 (同) & & 平家 & 36.50 \\
\hline 38 & 龙小屋（鍛治場炭小屡） & & 平家 & 60.00 \\
\hline 39 & 木蒸所 & & 平家 & 6.00 \\
\hline 40 & 炭小屋 & & 平家 & 20.00 \\
\hline 41 & 物置所（棟鉄所物置） & & 平家 & 36.00 \\
\hline 42 & 物置所 (䗲鉄所物置) & & 平家 & 40.00 \\
\hline 43 & 物置所 (蝀铁所物置) & & 平家 & 40.00 \\
\hline 44 & 物置所 (䗲鉄所物置) & & 平家 & 31.50 \\
\hline 45 & 職工長屋並焚出所（職工長屋） & & 平家 & 114.00 \\
\hline 46 & 属舍（職工長屋） & & 平家 & 47.25 \\
\hline 47 & 職工長屋（二番職工小屋） & & 平家 & 41.25 \\
\hline 48 & 属舍 & & 平家 & 51.00 \\
\hline
\end{tabular}

簿書 (7259) 『明治十五年二月開拓使工業課事務受渡畫類』中の「札幌旧工 業局構内建家並坪数調」による。（）内の建物名は北海道大学北方資料室所 蔵の「工業局器械所」図中のものである。竣工年日の不明なものは空欄とした。

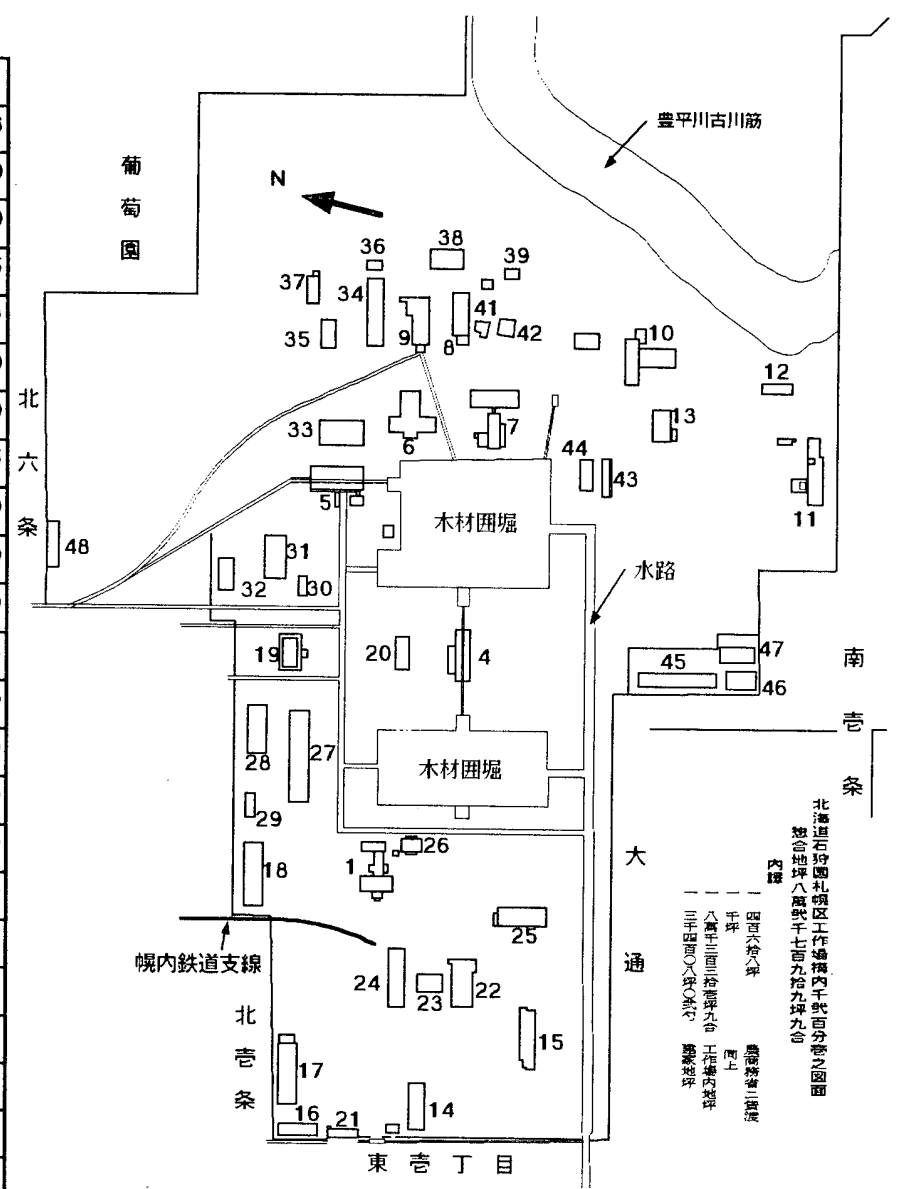

【図2】器 械場 構 内配 置 図

簿書（7764）中の「北海道石狩国工作場構内千式百分壳之图」による とあるように「葡萄植付試験場」として物産局勧業課人貸渡された。 また、明治 13 年 11 月幌内鉄道の手宮一札幌間開通後、札幌停 車場の東側の創成川をわたってまもなくの地点から本線と分かれ、 東 2 丁目 (雨竜) 通りを工業局構内一至る支線が設けられた。英 国人 T・W・ブラキストン (Thomas Wright Blakiston) の著書『蝦 夷地の中の日本』(『JAPAN IN YEZO』1883 年) ${ }^{17}$ の中に、「鉄 道は町 (札幌) の北端を通り、保護柵なしで、ほほ東西直線につく られた道路の一 (北5条通) と並行している。なせ町の中心す なわち官区と商区を分割する空地带 (大通) という鉄道をうまく受 け入れるようなところへ引か氺、敷設されなかったか理解しにく い。現在の路線位置は本線と工業局構内を結んでいる支線の追加工 事を必要とした。との記述がある。なお、この支線の位置は『北 海道志』中の「札幌市街図」(図 1) と図 2 に示されている。支線 は工業局庁舎前まて鋪設されていたことがわかるが、この周辺には、 原料の搬入およひ製品の搬出こ便利なように「木枯小屋、「板庫小、

「物置」などが配置されていた。

\section{4 檴内の主要施設の配置}

明治 5 年5月に開設した札幌工作場は、徐々にその施設を充実し ていく。明治 15 年 2 月廃使時までに、簿書 (7259)『明治十五年 二月開拓使工業課事務受渡書類』中の「札幌旧工業局構内建家並坪 数調」によれば、構内の建物は、48 棟、延 3408 坪 02 合となって

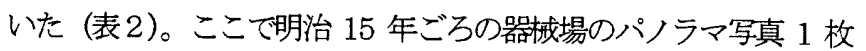
をあげておく。

また、図 2 および北海道大学附属図書館北方資料室所蔵の「工 業局器械所」図 (新選北海道史』第 3 巻 pp.496 参照) は構内の 


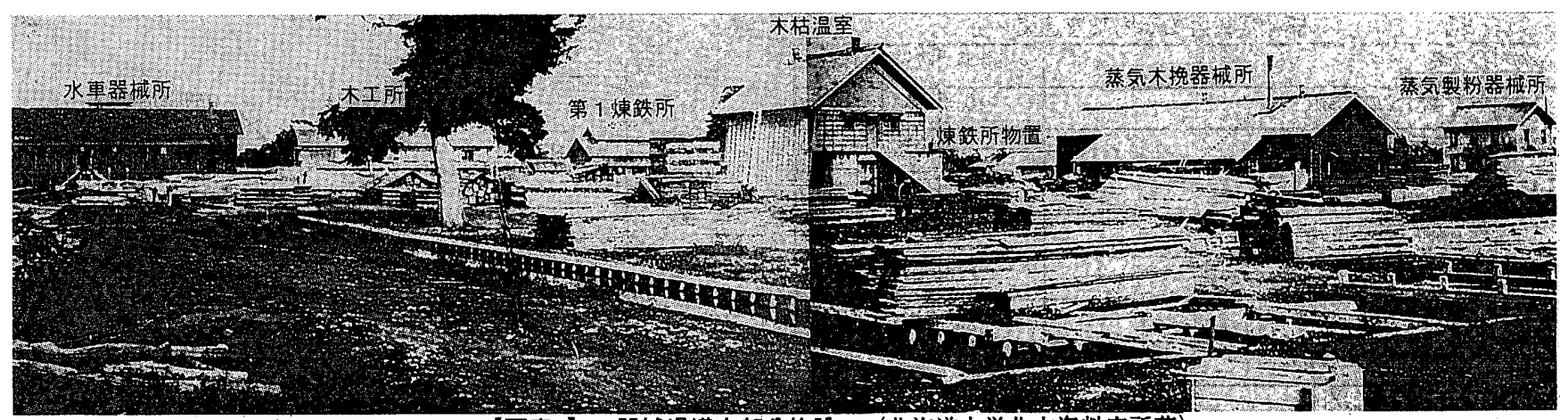

【写真1】器械場構内部分施設 (北海道大学北方資料室所蔵)

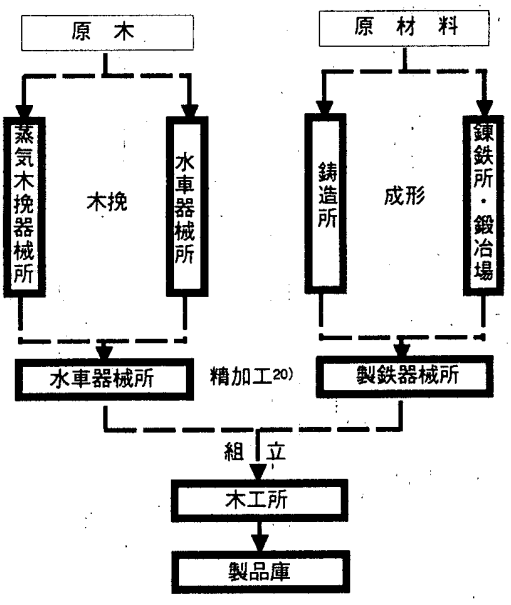

【図3】器械場作業系統
諸施設の全貌を示して いる。正門滄成川沿 いの現大通東 1 丁目 に設けられていた。正 門の突き当たりには工 業局庁舎（図 2 中の 1、以下同) が置か冰、 背後に 2 つの「木材 囲堀」(貯木池) が設 けられた。図測によれ ば、西側の「木材囲掘」 は、南北約 317 尺、 東西約 133 尺、東側 のものは、南北約 275 尺、東西約 229 尺であり、器械場西脇の創 成川から構内南側の木囲水路を通じて水が引がていた。なお プロンの日誌ぶ、「…貯木池はこれらの工場用に作ったのだここ から丸太を木工所 (水車器械所) の中几機械て運ぶ…上をる。

この2つの貯木池に挟まれた位置には蒸気木挽器械所 (4) があ り、その左 (北) 側は明治 13 年に建てられた木材乾燥所一门木枯 小屋」(20) である。この建物（2階建て、建坪 40 坪）について は簿書 (7141) 『工業報告書』中の「営繥報告書 明治 13 年」に、

「同年七月工業局構内二温木枯所ラ設ク土蔵造りニシテ四壁习堅 フシ室内常二暖炉 ヨ経過セザル材习使用セルモノハ漸次乾燥スルニ随ヒ空隙习生 スルモノアルラ以テ之レカ改良习謀ルナリ」

という記録がある。蒸気材㗊械所と木枯小屋の間にはボイラーと 乾燥ストーブ用の然料を置くと思われる「薪置小屋」18)があった。

東奥の北側には水車器械所 (5) とその事務所 (平家、14 坪)、 東側に本可所 (6)、鍊鉄所 (7)、さらに東奥に製鉄器械所 (9)、 鍛冶場 (8)、塗物所（37）などをそれぞれ配置していた。

木囲水路の南側には明治 9 年 11 月に建てられた製粉器械所 ${ }^{18)}$ が置か水、その後 (東側) に第 1 (10)、第2鋳造所 (11) と、 諸物品運搬用馬の廐 (13) ${ }^{19)}$ があった。

要するに、配置計画の特色は建築施設を構内の西半分に集中し、 $2 つ の$ 「林相掘」とその水路を中心とすることである。即ち、東、 北部には倉庫群、西、南部には金属加工工場群、中部の「木材囲掘」 の廻りには木材加工関係の「蒸気器械所」、「水車器械所小「枯小 屋」および「木工所」がそれぞれ配置されていた。器械場全体の製 造プロセスを建築施設との関係で示すと、作業系統図 ${ }^{19)}$. (図 3)-の ようになる。本図怯、器械場搆内の諸作業所の製品と諸作業場で装
置されていた機械の種類、性能の分析の上、作成したものである。

\section{5 器㳦場の木材加工工場}

$5-1$ 蒸気木挽器城所（蒸気器械所、蒸気機械所）

蒸気器械所は先に述べたようにS・クラークが担当し、5年 6 月 着工、同年7月に䇋工した (表 3中 1、2)。外観は、字真 1 で知る ことができるが、木造平家、切妻屋根の建物で、棟上に見える鉄理 突 1 基は蒸気機関の煙突であろう。母屋の北側に下屋が延び、外壁 は篰子下見張り、母屋の西側妻に庇付きの大きな入口が設けられて いた。前述の「工業局器械所」図には、「木材囲掘」から直ちに工 場内に原木或いは製品を運搬するための軌道が見られる。なお、図 測により、母屋は桁行約 90 尺、梁間約 27 尺、下屋は 52 尺×10 尺である。

蒸気梚器械所に装置された機械こついては『北海道志』の 14 巻産業に

「蒸気木挽機械所明治五年七月建築圓鋸一 7 座ス二十五馬力汽缶 ヨ以テ運転ス。」

とある。表 4 に明治 12１4 年の本所とあわせ水車器械所、木工所 の生産高を示した。製品は婏分の木材である。機械と製品からみる と、蒸気木婏器械所俅車器械所と共に材の婏分けを担ったと推 定する。次のケプロンの日誌の一文にここの器㧔所の生産様子が記 されている。

「1872年8月 10 日

…丸鋸は蒸気で動かす予定で、すでに淮備ができている。昨日、 エンジンの蒸気を上げ、継ぎ目を点検した。今日は、鋸を運転し て初めて板を作った。アイヌの人達は汽笛の音にすっかり驚き、 実に賬やかである。ついこれが知れ渡ると、大勢の日本人やア イヌが仕事場を取り巻き、込み合いながら、一目この怪物を見よ うとする。そして、びっくりした顔で、径2フィート長さ 14 フ イートの丸大が、機械の一端に載り、十分間で板になって、他の 端から飛び出すのを眺める。小さな丸大なら僅か7分、ある丸大 は、5分というのが害状である。」

\section{$5-2$ 水車器械所（水車器诚製作所）}

ホルトが担当した水車器械所は、明治5年 6 月建設に着手 「劃、 地八拾坪二階造二テ、地平ヨリ五尺下二土害习据、，尚ホ深七尺餘 幅九尺横一丈八尺二掘下ケ水積千九百四十四立方尺ノ水槽习設ケ、 元車四十八インチヨ装置冰八創成川ヨリ木囲堀习通シテ之ヨ引用 ス‥」 ${ }^{21}$ 。また、ケプロンの明治 5 年 7 月 30 日の日誌に、次の記 述がある。

「現在、建物を1 軒建築中で、そのなかでは、今はコントロール できる水力を利用し、強力なタービンを一動かすはずである。 
これで、製粉機、鋸 1 組、平削り盤、そのほか立派な木材をどん な形にでもできる、いろいろな機械を動かすはずである。

明治 6 年 2 月に、円鋸機など 6 種類木材加工機械のほかに、粉
磨器 ${ }^{22} 1$ 台を備え付けていた。粉磨機械装置は、小麦粉を製粉す るためのものであったが、粉に木屑や塵埃等が混入して売り物にな らず、明治9年敷地内に新たに蒸気を動力とする「製粉器械所」を

【表3】器沩場構内 の部分施設表

\begin{tabular}{|c|c|c|c|c|c|c|c|c|c|c|c|}
\hline & & & & \multirow{2}{*}{$\begin{array}{ll}\text { 地名 } \\
\end{array}$} & \multicolumn{2}{|l|}{ A $0>$ 可 } & \\
\hline \multicolumn{2}{|r|}{ 紀年 } & 工事区分 & 国 & 郡区 & & 建物 & 棟数 & 坪数 & 起工 & 埈工 & 経赛 \\
\hline 1 & 5年 & 新築 & 石特 & 札晥 & 東創成川通 & 蒸気木换器找所 & 1 & 58.00 & 6月 & 7月 & 143.064 \\
\hline 2 & 10年 & 新築 & 石狩 & 札幌 & 東創成川通 & 蒸気木挽器械上家 & 0 & 81.25 & 4月 & 5月 & 880.008 \\
\hline 3 & 8年 & 新築 & 石狩 & 札幌 & 東創成川通 & 工作場木挽水車器械所 & 1 & 111.00 & 5年6月 & 3月 & 6363.456 \\
\hline 4 & 8年 & 新築 & 石狩 & 札塂 & 東創成川通 & 木工染場 & $\overline{1}$ & 52.00 & 5月 & 6月 & 742.186 \\
\hline 5 & 11年 & 新築 & 石狩 & 札幌 & 東創成川通 & 吹貫小屋並木工所建足 & 0 & 153.00 & 10月 & 12月 & 903.420 \\
\hline 6 & 12年 & 新築 & 石狩 & 札幌 & 東創成川通 & 鍛治器械所 & 1 & 96.50 & 11年9月 & 7月 & 3428.3 \\
\hline
\end{tabular}

新設していた ${ }^{23)}$ 。同年 7月、機械の運転を試みた。 明治6年（1873）7月 7 日のケプロンの日誌を引 用しておく。

「今日、タービンの動翼に水を通し、各種の転伝動 装置を始動した。やがて，石臼注粉をひき、製材、 平削り、さねはぎ、溝彫りの機械、及び屋根板や木 ずり等などを作る機械は、すべて作業を開始するは ずである。」

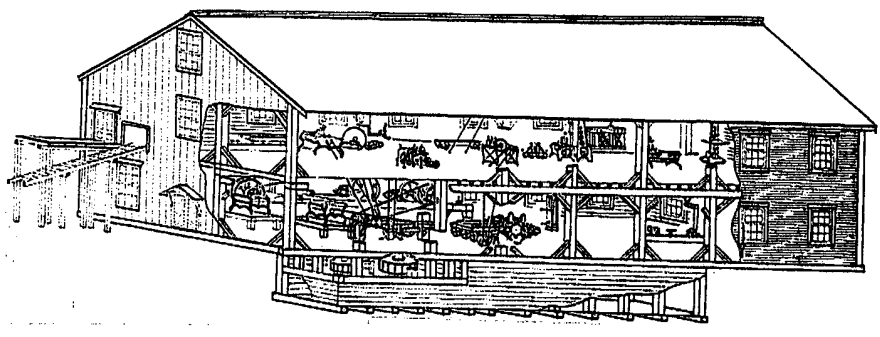

【図4】水車機械所

【表 4】器棫所の生産状況 (明治 12〜明治 14 年)

\begin{tabular}{|c|c|c|c|c|c|}
\hline 施設名 & 目種 & 12年 & 13年 & 14年 & 備考 \\
\hline 蒸気器械所 & 挽分蜸 (通) & 79,982 & 89,640 & 68,792 & \\
\hline \multirow{3}{*}{ 水車器械所 } & 挽分（通） & 139,764 & 64,744 & 141,142 & \\
\hline & 柾（束） & 16,044 & 19,940 & 9,943 & \\
\hline & 家材（挺） & 167,710 & 118,753 & 275,336 & $\begin{array}{l}\text { 板、障子、小舞、 } \\
\text { 中貫、实㚘引など }\end{array}$ \\
\hline \multirow[t]{6}{*}{ 木工所 } & 家材類 (個) & 6,880 & 0 & $\overline{0}$ & $\begin{array}{l}\text { 障子、部戸、襖な } \\
と ゙\end{array}$ \\
\hline & 建具類 (個) & 3,837 & 6,647 & 4,806 & 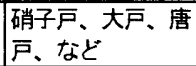 \\
\hline & 農具類（個） & 2,092 & 6,038 & 16,955 & $\begin{array}{l}\text { 鋤の柄、䤵の柄、 } \\
\text { 犁手など }\end{array}$ \\
\hline & 車並檽類（個） & 812 & 455 & 44 & $\begin{array}{l}\text { 馬車、荷車、人力 } \\
\text { 車の胴など }\end{array}$ \\
\hline & 家具類（個） & 6,013 & 7,546 & 9,195 & $\begin{array}{l}\text { テーブル、屏風、 } \\
\text { 燭台、箪筜など }\end{array}$ \\
\hline & 道具、機湘類 (個) & 2,549 & 8 & 9 & $\begin{array}{l}\text { 井戸車、草の器、 } \\
\text { 鰊筒、鉢など }\end{array}$ \\
\hline \multirow[t]{3}{*}{ 製鉄所 } & 麟具類（個） & 5 & 33 & 38 & $\begin{array}{l}\text { 鎙、锹、犁、馬鉄、 } \\
\text { 播種器など }\end{array}$ \\
\hline & 道具、機械類 (個) & 543 & 519 & 212 & $\begin{array}{l}\text { 大工工具、缶切 } \\
\text { 器、油差など }\end{array}$ \\
\hline & 雑品 (個) & 96 & 481 & 240 & $\begin{array}{l}\text { 馬車の鉄物、門屝 } \\
\text { 鉄物、釗など }\end{array}$ \\
\hline \multirow[t]{5}{*}{ 錆造所 } & 農具類 (個) & 77 & 121 & 36 & 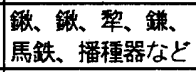 \\
\hline & 道具、機械類 (個) & 589 & 58 & 284 & $\begin{array}{l}\text { 大工工具、缶切 } \\
\text { 器、油差など }\end{array}$ \\
\hline & 家具類（個） & 619 & 190 & 92 & $\begin{array}{l}\text { 家具铁物、鉄鎖な } \\
\text { ど }\end{array}$ \\
\hline & 鍋釜類（個） & 0 & 261 & 219 & 鍋、釜、鉄瓶、釬 \\
\hline & 雑品（個） & 16 & 4,458 & 3,230 & $\begin{array}{l}\text { 馬車の鉄物、門屝 } \\
\text { 鉄物、釘など } \\
\end{array}$ \\
\hline \multirow[t]{4}{*}{ 䗲鉄所 } & 農具類 (個) & 3,528 & 1,830 & 1,749 & $\begin{array}{l}\text { 鉺、鉜、犁、鎌、 } \\
\text { 馬鉄、播種器など }\end{array}$ \\
\hline & 道具、機械類 (個) & 9,053 & 1,100 & 402 & $\begin{array}{l}\text { 大工工具、缶切 } \\
\text { 器、油差、など、 }\end{array}$ \\
\hline & 家具類（個） & 17,912 & 285 & 1,740 & 家具鉄物など \\
\hline & 雑品（個） & 777 & 72,254 & 65,853 & $\begin{array}{l}\text { 馬車の鉄物、門扉 } \\
\text { 鉄物、釗など }\end{array}$ \\
\hline
\end{tabular}

『開拓使事業報告 第参編』と簿書 (2527) 『明治十一年三月 事業浻草調 製作係』 による
翌 7 年 1 月汇は、「水車機械所旋床、圓鋸、粉磨 三器习装置スルニ元車馬力充分ナラス且機械五種漸次装置二由リ木 鉄製三十馬力元車一個习摸造シ又梯子ヨ架シ木囲掘ヨリ材木习直二 楼上二曳揚儿為入三馬力元車一個 7 增置ス」24。明治 8 年 3 月 19 日水車器械所はようやく落成を迎えることになる（表 3 中 3 )。水 車器械所は図測から、桁行約 97 尺、梁間約 40 尺である。

簿書 $(7260)$ 『明治十五年開拓使引継書類』中の「石狩国札幌区 東創成町工業局構内トルビン工作器械之図」25) (図 4)は、この工 場の建物、水槽、水車及ひ製材機械の様子を描いたものである。建 物は 2 階建て、切妻屋根。妻側の外壁は竪羽目板張り、側面の外 壁は下見板張り、空は上げ下げ空である。内側こ方杖をつけ、また、 木囲堀から木材を直ちに2階の作業場に引き上げるための梯子が見 える。水車は地下に置加、その配置形式より推寸る之、日本の伝 統的なものと違い、㹂軸露出式タービン水車であろう。また、図 2 により、水は水車器械所の南の「木材囲堀」から水車器找所地下の 水槽室に流れ込み、その北側の水路に流れ出すと判断できる。

この器械所の設備については『北海道志』14 巻産業に

「明治六年五月建築二層構造圓鋸大中小三薄圓鋸一竪鋸一柾挽一 旋床一大鉋一小鉋一圓鉋一迴挽鋸一横切鋸一帯鋸一柄付器一穴彫 器一 $习$ 座ス水車三合テ百一馬力創成川引テ運転ス」

とあり、製材機械は、合計 13 種類 15 台があげられていた。それ らは2つに大別できる。一つ、普通製材用機械類の、圓鋸、薄圓 鋸、竪鋸、横切鋸、帯鋸である。圓鋸と帯鋸は、挽き割り用、横切 鋸は木材を横切りする機械であるが、それ以外の薄圓鋸は薄板挽き 割り用機械，竪鋸は丸材や角材の小割や横断用機械である。

もう一つは材特別加工設備である。前述の旋床は、ダライバン （ドイツ語で drehbank）とも称され、繰物細工用機械、廻挽鋸は 屈曲模型や車輪等を挽く機械である。柾挽（鋸）は専ら「水車器械 柾」の製造用、周知の通りアメリカの屋根莫き板シングルの製造技 術を導入したものである。また、水車器械所ではシングルのほが も、丸太の婏分と建具、角材、中貫、小舞というような家材の生産 も行われていた。

5-3木工所 (木工塗場)

水車器械所の東側の木工所は、明治8年6月に竣工した建物で、 その後、明治 11 年 10 月に増築された（表 3 中 4、5)。建物は十 字型平面、2 階建てであることがわかる。明治 14 年本所には、係

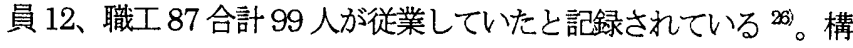
内の他所に比べて、雇用人数は最も多い。また、機械設備の記述は ないが、他器械所の半製品を建具、家具などの製品に組立てるため 
の工場（組立職場）であろう。

\section{6 器诚場の金属加工工場}

製鉄器械所（鍛冶器找所ともいう。表 3 中 6) については、開 拓使事業報告，第参編』によって、建物を建設すると同時に、水路 が堀割され、元鉱山機械に属した 12 馬力汽缶 1 個及び 23 馬力水 車 1 個」を整備し、蒸気動力と水力を使っていたことがわかる。 また、 10 年東京で購入した製鉄用機械 5 種、元の銭工所の旋床、 鑚剪 2 種が本所々設置された。北海道志』14巻産業には

门明治十二年三月建築：蒸気錧器一錐操器二旋床器四金属維削器

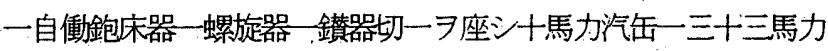
水車一 Э以于運伝ス」

とあり、金属加工用機械は 7 種類、11 台があげられていた。蒸気

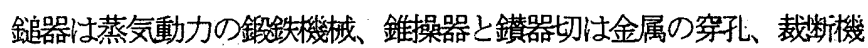
械である。

鋳造事業は、明治6 年5月、板庫 1 棟を建て、一時鋳造所とし て、鋳造工 1 人を函館に募り、伝習者 2 人を付忛農工器具の製造 を開始した。 8 年 2 月には、更に 60 坪の鋳造所（第1鋳造所）を 301 円 77 銭 81 厘を費やして新築し、のち.11 月に若干の改造を行 った。第 2 鋳造所は 11 年 1 月に䇋工、建坪は 128 坪 5 合であった。 ここでは専ら鰊釜の鍀造を行っていた。

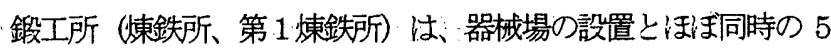
年 5 月、鍛工 12 人を東京から招き、翌年 8 月汽缶の製造、修理に 必要なホッスハング2 1 1 基を東京より購入して、銑工所に備え付 けていた。7年1月には生産場所か狭くなったため、その東側々新 たに建物（鍛冶場、第 2 煉鉄所）を新築し、その後明治 9 年 10 月 に度量衡 3 器中鉄物（鉄定規など）を製造するため、さらに 14 坪 を増築した。

第 1、2 鍀造所と第 $1 ， 2$ 棟鉄所湔述の「工業局器械所」図に よって、作業中の煙と熱を出すため、それぞれの作業場の屋根に換 気口が設けられていたことがわかる。また、両所の機械設備の記述 がないが、表 4 に 12 年から 14 年の 3 工場の製品種類と生産高を 示す。

\section{7. 結び}

本稿は、札幌本庁工業局の器械場について以下のことを明らがに した。

(1)立地計画 : 開拓使は、創成川を丸太搬入と水動力提供の目的にあ て、器械場をその東畔に設置した。また、明治 13 年幌内鉄道の手 宮一札幌間開通後、器械場および付近の工場の運輸のため、本線と 工業局構内を結ぶ支線が鋪設されていた。

(2)構内の配置 : 器械場配置の特色は、施設を西半分に集中し、且つ 2 つの「木材囲掘」とその水路を中心とすることである。東、北部 に泣倉庫群、西、南部には金属加工工場群、中部の、木材囲掘」の 廻りには木材加工関係の「蒸気㭠器械所」「水車器械所」などと総 組立職場の「工所がそれぞれ配置されていた。

(3)建築施設 : 施設としては、49 棟、総計 3,408 坪 (11,300 余党) にのぼる、当時としては特筆に值する規模の総合工場であり、15 台の木材加工機械と、地階の竪軸露出式タービン水車を備えた木造 2 階建ての水車器㧔場など、注目すべき建物を見ることができた。

以上、開拓使の施策の基幹として、アメリカの先准技術を導入し て本格的な工業施設を目指した札幌本庁工業局器械場の概要を見て
きた。今後は工業局以外の物産局管轄の諸施設や各支庁管轄下の産 業施設を考察していきたい。

\section{〈娚辞〉}

史料を賜った 北海道立文書館と北方史料室の方々に感謝の意を 表します。

\section{注却}

1）大蔵省『開拓使事業報告』、明治 18 年、昭和 58 年 4 月復刻

2) 大藏省『北海道志、明治 17 年 3 月、昭和 43 年 10 月復刻

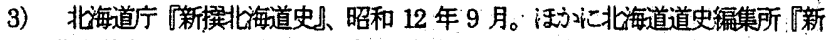
北海道史小、昭和 56 .年 5 月、など

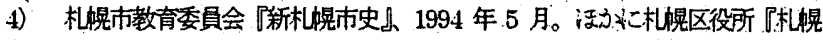
区史小、明治 44 年 7 月。札愰市役所『札幌市史小、昭和 33 年 4 月、など

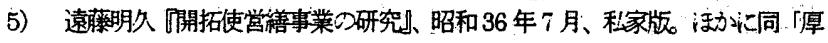
別水車器找所に二小儿、北海道産業考古会研究報告、1990.12.1

6）本稿の一部概要法、開拓使札幌本庁管轄工場施設に関寸る研究」平成 8 年 度日本建勧学会北海道支部叝告集で発表した。

7） ホランシ・ケプロン著、西島照男歌 : ケプロンの日詰 蝦夷と江戸、昭和 60 年 2 月

8）北海道新閍社『北海道大百科事典』(上)、昭和 56 年 8.月、pp.453

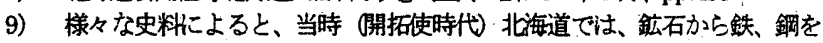

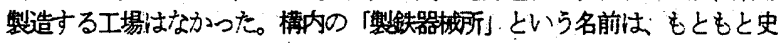
料中の建物名で、文章でそのまま引用した。厳密な定義を言えば、「金属加 工所」だと思われる。

10）前掲『開拓使報告事業 第参編、pp.741によれ认゙、明治 12 年 2 月、札幌 上り南方 4 里余の厚別山官林地内汇厚別水事器械折を建設し、専ら「水車器 械柾」といら屋根板を製造した。

11）北海道立文書館所蔵心簿書 7259 『明治十五年六月三十日 開拓使工業辣事 務受渡書類』中汇掍载

12）黒田清隆（1840 1900）注明治 3 年 5 月開拓使次官江就任し、同 15 年 1 月に開拓使長官を免ぜち机，参議・農商務卿西郷従道、長官を兼任した。

13） アメリカ人N・W・ホレト $(\mathrm{N} \cdot \mathrm{W} \cdot \mathrm{Holt})$ 汴、明治5年2月汇機械透転 頭取とし下㕍扮动，同9年6月汇帰国した。

14）アメリカ人サンドフォード・クラーク（S andford Clark) は、明治5年 3 月に機械方補助として雇犼机同 7 年 3 月に满期。

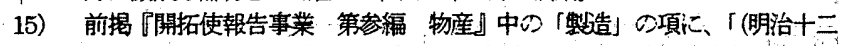

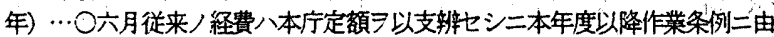

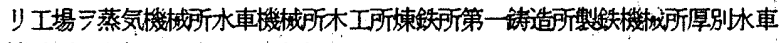
機械所ノ七部二区分シ…」とある。

16）魚粕の製造用道具である。姚海道大百科事典』(下)によれば、漁期遅れ

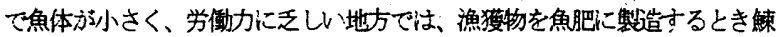

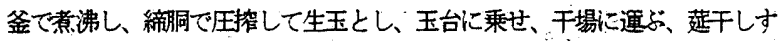
る」とある。

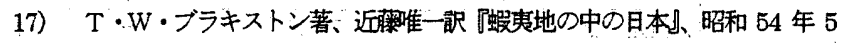
月

18）。図2の中渵いていない。

19）前掲『開拓使報告事業第参編 物産』中の「製造了の項儿、「(明治八年)

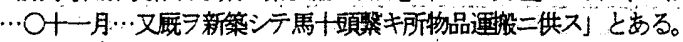

20）图中の「精加工，とは、例之は，鉄工製品を作る場合、煉鉄所や錛造所で 鉄を銠斜、鍀造して形をつくり、これを製鉄所て金属加工機械を使って精製 すること、また、水車器械所の木工機械を使って、建具類、家具類、農具類 などの木製品部分を細かく加工することの意味で使用している単語で、一般 的な語句ではない

21）前掲『開拓使報告事業 第参編 物産』 pp.737。その水槽の寸法により計 算すると、水䅡性 1134 立方尺である。また、後述の図 4 に描いた水槽の横 と比較すると、かなり大きい差異があるが、「横一丈八尺」注間違いである ら。ここで法摘するにとどめる。

22）『開拓使事業報告 第参編》 pp.739 て㤦用の単語、蔽粉器械のこと。

23）前掲『開拓使報告事業：第参編 物産』中の「製造了の項に; 「(明治九年)

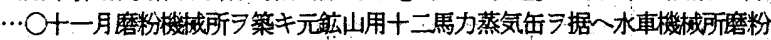
器Э移ス是其木材挽割等ノ諸楼械二接三鹰埃混入スルラ以テナリ」とある。

24）前揭 『開拓使報告事業 第参編 物産』 p p.738

25) 本図江簿書 7259 中の写真を中原為雄氏模写後、北海道大学北方資料空に薪 贈したものを複写

26）前掲『開拓使報告事業 第㚐編 物産及 $\mathrm{pp}$.743

27）前掲『開拓使報告事策第参編，物産』中の「製造了の項认、「(明治六年)

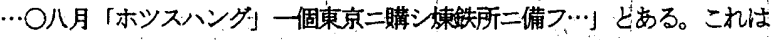
金属の穿孔、裁断機械であり、英名はHoles Punch であろう。

(1998年 5 月 25 日原稿受理, 1998年10月16日探用決定) 